\title{
Effect of aromatherapy on the pain of arteriovenous fistula puncture in patients on hemodialysis: a systematic review
}

\author{
Ayşegül Yildız \\ Dialysis, Cappadocia University, Ürgüp, Turkey, and \\ Seda Şahan \\ Fundamental of Nursing, Bakircay Universitesi, Izmir, Turkey
}

\begin{abstract}
Purpose - This study aims to determine the effect of aromatherapy used in reducing the pain caused by fistula puncture in hemodialysis patients.

Design/methodology/approach - In this study, the effect of aromatherapy application on fistula puncture was analyzed and carried out by scanning the relevant literature. The literature review was conducted between August and October 2020. While reviewing the literature, the authors used "aromatherapy," "pain," "fistula," "puncture," "hemodialysis" keywords and various combinations of these; moreover, Google scientist, Pubmed, Cochrane, ScienceDirect, Web of Science, Medline and Ovid databases and studies, which were conducted in the last 10 years were reviewed. As a result of the literature review, 1183 studies were reached and seven of them were included in the study by taking the inclusion criteria into account.

Findings - The randomized controlled studies are six studies and nonrandomized controlled experimental 1 study were added to the scope of the study and seven studies were included in the sample. In these studies, personal information forms developed by the researchers as data collection tools and the VAS scale, Numerical pain rating, the numeric rating scale were used to evaluate pain.

Practical implications - It has been determined that aromatherapy application in hemodialysis patients has positive effects on reducing pain due to puncture fistula intervention.

Originality/value - This study provides reduction or elimination of fistula needle insertion pain in hemodialysis patients.
\end{abstract}

Keywords Aromatherapy, Hemodialysis, Fistula, Puncture, Pain

Paper type Review

\section{Introduction}

End-stage renal failure (ESRF) is a serious health problem with a rapidly increasing prevalence worldwide, resulting in high rates of mortality [1]. In ESRF patients, the most frequent and preferred method to restore the disappearing kidney functions is hemodialysis treatment $[2,3]$. For hemodialysis treatment to take place, the medical provider must establish a connection between the device and the patient by vascular access [4]. This method of vascular access in dialysis patients is known as an arteriovenous fistula (AVF). AVF is created as a result of a surgical procedure that connects an artery and a vein under the skin [5]. For patients to receive hemodialysis treatment, a needle must be inserted into the AVF each time. Considering that patients receive dialysis treatment at least three times a week, patients receive needle interventions quite frequently $[6,7]$.

(C) Ayşegül Yıldız and Seda Şahan. Published in Journal of Health Research. Published by Emerald Publishing Limited. This article is published under the Creative Commons Attribution (CC BY 4.0) licence. Anyone may reproduce, distribute, translate and create derivative works of this article (for both commercial and non-commercial purposes), subject to full attribution to the original publication and authors. The full terms of this licence may be seen at http://creativecommons.org/licences/by/4.0/legalcode 
JHR

36,6

1188

Due to the fistular needle intervention, which is compulsory for conducting hemodialysis treatment, patients experience stress and anxiety. Patients often complain about the pain caused by the needle intervention [8,9]. It is important to address the pain and concerns of patients with simple interventions and safe methods.

Pain management is one of the most basic nursing interventions. By controlling pain, patients may have increased satisfaction and improved quality of life [6]. Pain management may be achieved by nonpharmacological and pharmacological methods. Pharmacological treatments are considered as risky because they may induce addiction in the patient and cause side effects and complications [10]. On the other hand, nonpharmacological methods are recommended because they are inexpensive and cause fewer side effects and complications $[1,11]$. Among nonpharmacological pain management precautions, recent studies have reported that practices such as distraction, skin stimulation methods, cold applications and aromatherapy may be used as effective and safe methods to alleviate pain $[1,12]$. In aromatherapy, essential oils obtained from flowers and other plant parts are inhaled by patients or applied on patients' skin to reduce stress, anxiety and concerns in order to achieve pain management $[9,12]$.

Scientists report that the stimulating feature of essential oils used in aromatherapy is due to the fact that their chemical structures closely similar to hormones [13]. The penetration potential of these oils into the subcutaneous tissues is one of the important effects of this treatment. The mechanism of action of essential oils involves the integration of essential oils into the biological signaling of receptor cells in the nose during inhalation of the oil. The signal is transmitted to the limbic and hypothalamus regions of the brain through the olfactory bulb [14]. These signals cause the brain to release neurotransmitters such as serotonin, endorphins and so on. This process provides a sense of relaxation by connecting our nerve cells and other body systems. Serotonin, endorphins and noradrenaline are released from calming, euphoric and stimulating oils, to achieve the desired effects on the mind and body [15].

The effects of essential oils on the central nervous system (CNS) may vary according to the properties of the oil used. For example, rosemary is an herb rich in resin, tannic acid and an essential oil that causes CNS stimulation. Its active ingredients are bornyl acetate, borneol with other esters and special camphor similar to that found in myrtle, cineole, pinene and camphene [16]. Its stimulating property on the nervous system is beneficial in hysteria and paralysis [17].

Other examples are linalool and linalyl acetate, which are found in lavender. These compounds cause CNS depression and are readily absorbed into the skin during massage. Linalool exerts sedative effects. Linalyl acetate exhibits pronounced narcotic effects $[13,18]$.

In addition, there are many essential oils with antibacterial, antifungal, antiviral, antiinflammatory, antitumor, antioxidant, spasmodic and hormonal effects [13]. Various types of essential oils can be used in the management of problems such as anxiety, agitation, stress, compulsive behaviors, fatigue, insomnia, burnout, memory loss and pain that patients complain about $[19,20]$. The essential oils that are ideal for pain management include rosemary, eucalyptus, lavender, German chamomile, manuka, sweet marjoram, dwarf pine and ginger [13].

Nurses are the primary healthcare service providers for patients receiving hemodialysis treatment. Therefore, nurses usually place fistula needles on the patients' AVF. They also plan and implement the correct interventions for pain that emerges due to cannulation and assessing the effectiveness of the implemented method [6]. Our study aimed to determine the effects of aromatherapy on pain that occurred during fistula needle intervention in ESRF patients receiving hemodialysis treatment.

Essential oils are generally used safely with minimal side effects. The most common side effects are eye, mucous membrane and skin irritation and sensitivity, especially due to oils containing aldehydes and phenols. Allergic reactions have been reported in a few cases, 
particularly with topical application. To our knowledge, there is no study showing that oils are harmful when used in aromatherapy. Recommendations for the safe use of essential oils in aromatherapy include: (1) diluting the essential oil to be used for aromatherapy massages at a rate of $3 \%$ or less, (2) using a lower concentration when used in individuals younger than 15 years of age, (3) avoiding essential oils completely during pregnancy, (4) performing a patch test to eliminate concerns before application, if there is uncertainty about a possible reaction. It is recommended to use a $1 \%$ concentration initially for the protocol. Essential oil vapors should not be inhaled directly by people with a diagnosis of asthma or those reporting airway hyperreactivity for odor. In this group, the use of a maximum of $1 \%$ concentration of essential oil is recommended for aromatherapy massage [21].

Although different applications exist for fistula needle intervention pain in ESRD patients, interventions related to aromatherapy are often not used in clinical practice due to concerns, difficulty in use, lack of knowledge and inexperience [22, 23]. This study aims to summarize the results of previous randomized controlled and quasi-experimental studies in patients receiving dialysis treatment [24]. Our study systematically reviewed articles to determine the effect of aromatherapy applied during fistula needle intervention on pain in ESRD patients receiving hemodialysis treatment. We also strive to ensure that nurses know more about aromatherapy and their effects in clinical practice with hemodialysis patients [25].

\section{Methods}

We conducted a systematic review guided by the Preferred Reporting Items for Systematic Reviews and Meta-Analyses (PRISMA) Checklist reporting item for systematic reviews $[26,27]$.

\section{Search strategy}

We reviewed the relevant literature on the effects of aromatherapy application on needle intervention pain in articles published from 2010 to 2020. The literature review was conducted between August and October 2020. We used the keywords of "aromatherapy," "pain," "fistula," "puncture" and "hemodialysis" and various combinations of these, to identify articles in the Google Scholar, PubMed, Cochrane, ScienceDirect, Web of Science, Medline and Ovid databases.

\section{Inclusion and exclusion criteria}

Our inclusion criteria specified that all studies in the English language published from 2010 to 2020, which investigated the effects of aromatherapy application on needle intervention pain in hemodialysis patients, were included in this systematic review. We excluded other systematic reviews, descriptive studies, case reports, letters to the editor, studies where a different method was applied to the experiment group in addition to aromatherapy, studies conducted on animals and other studies that were not suitable.

Study titles retrieved by the search were assessed for inclusion by one reviewer. A sample of excluded titles was checked by a second reviewer. Potentially relevant abstracts and full texts of articles were assessed by two reviewers. We resolved any discrepancies through discussion.

\section{Data collection}

We used the PRISMA statement to guide our systematic review. We used the EndNote X9 program to save copies of the articles and separate out duplicate articles. We had a consensus on the studies that were included in this study. There was no disagreement between the authors. 
JHR

36,6

\section{0}

Study quality assessment

The quality of the studies included in the review was assessed by two different tools. To assess randomized controlled studies, the "Risk of Bias" checklist from the Cochrane Collaboration was utilized [28]. The bias of randomized controlled studies was assessed under seven categories (Table 1). For the quasi-experimental studies, the checklist from the Joanna Briggs Institute was used [29]. The checklist was assessed in nine steps (Table 2).

\section{Ethical issue}

This study used only publicly available, non-identifiable data and thus did not require human subjects review.

\section{Results}

After searching the aforementioned databases with the specified keywords, we identified 1183 studies. Due to duplication, 241 studies were removed from the review. In total, 922 other studies were eliminated after we examined their titles and abstracts for relevancy. Thirteen studies that did not fit the inclusion criteria were excluded. For our systematic review, we examined seven studies that evaluated the effects of aromatherapy application on needle intervention pain (Figure 1). Table 3 summarizes the characteristics of the studies included in the systematic review.

In their study examining the effects of sweet orange aromatherapy on pain and anxiety during needle placement in hemodialysis patients, Reyes et al. [9] dripped 3-4 drops of sweet orange oil on a piece of cotton before needle intervention for patients in the experimental group. Patients inhaled the sweet orange oil from a distance of $4-5 \mathrm{~cm}$ for $5 \mathrm{~min}$. The control group had a breathing exercise for $3 \mathrm{~min}$. Each patient received the treatment one time. The pain score in the experimental group decreased from 2.04 to 0.80 after aromatherapy, showing a strong effect. Lower pain levels were found in the patients receiving sweet orange aromatherapy compared to those that completed breathing exercises $(\phi<0.001)$.

\begin{tabular}{|c|c|c|c|c|c|c|c|}
\hline Study & $\begin{array}{l}\text { Was technic } \\
\text { Random } \\
\text { sequence } \\
\text { generation }\end{array}$ & $\begin{array}{l}\text { Allocation } \\
\text { concealment }\end{array}$ & $\begin{array}{l}\mathrm{k} \text { of bias appli } \\
\text { Blinding of } \\
\text { participants } \\
\text { and } \\
\text { personnel }\end{array}$ & $\begin{array}{l}\text { Blinding of } \\
\text { outcome } \\
\text { assessment }\end{array}$ & $\begin{array}{l}\text { Incomplete } \\
\text { outcome } \\
\text { data }\end{array}$ & $\begin{array}{l}\text { Selective } \\
\text { reporting }\end{array}$ & $\begin{array}{l}\text { Other } \\
\text { sources } \\
\text { of bias }\end{array}$ \\
\hline $\begin{array}{l}\text { Thenmozhi } \\
\text { and } \\
\text { Pauline, } \\
2020 \text { [12] }\end{array}$ & + & + & ? & ? & ? & + & - \\
\hline $\begin{array}{l}\text { Kilic Akca } \\
\text { et al., } 2020 \\
\text { [30] }\end{array}$ & + & + & ? & ? & + & + & + \\
\hline $\begin{array}{l}\text { Tasan et al., } \\
2019 \text { [31] }\end{array}$ & + & + & ? & + & ? & + & - \\
\hline $\begin{array}{l}\text { Ghods et al., } \\
2015 \text { [8] }\end{array}$ & + & + & ? & ? & - & - & - \\
\hline $\begin{array}{l}\text { Bagheri- } \\
\text { Nesami } \\
\text { et al., } 2014 \\
\text { [33] }\end{array}$ & + & + & + & + & $?$ & ? & ? \\
\hline
\end{tabular}

Table 1.

The Cochrane collaboration's tool for assessing risk of bias in the systematic review of effect of aromatherapy on arteriovenous fistula puncture on hemodialysis patients, 2010-2020
Note(s): (+) Yes, technique to reduce bias was successfully used. (?) Unclear if technique to reduce bias was used. (-) No, technique to reduce bias was not used 


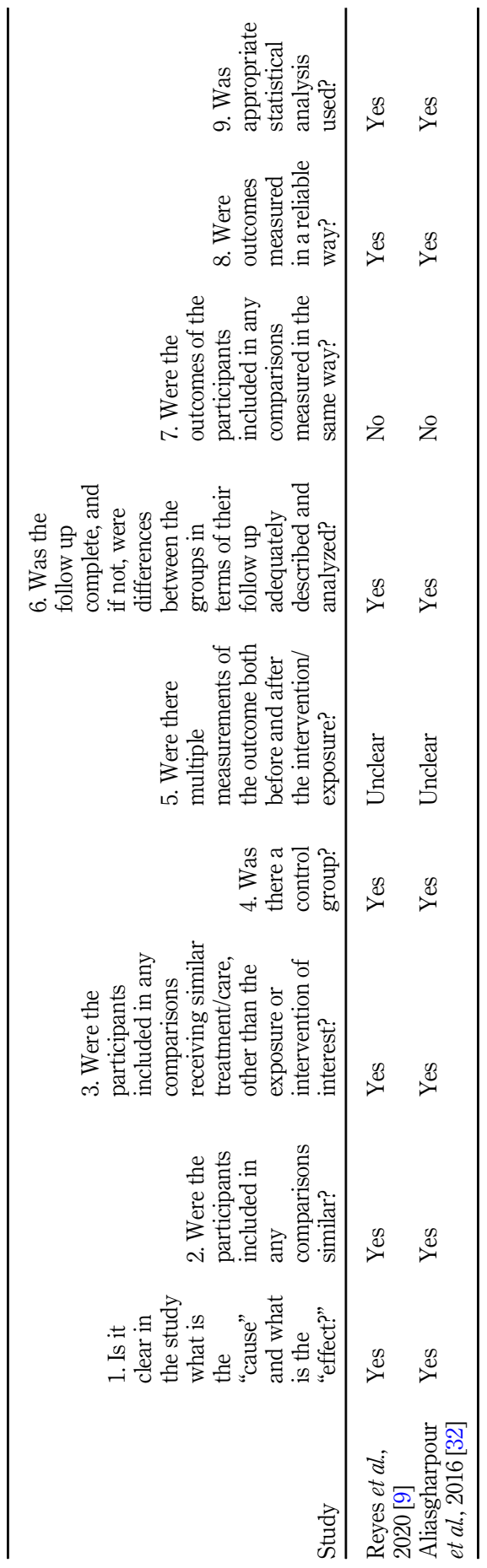

Table 2.

Checklist for quasiexperimental studies in the systematic review of effect of aromatherapy on arteriovenous fistula puncture on hemodialysis patients, 2010-2020 
JHR
36,6

\section{2}

Figure 1.

PRISMA flowchart of studies published from 2010 to 2020 included in systematic review of effect of aromatherapy on arteriovenous fistula puncture on hemodialysis patients
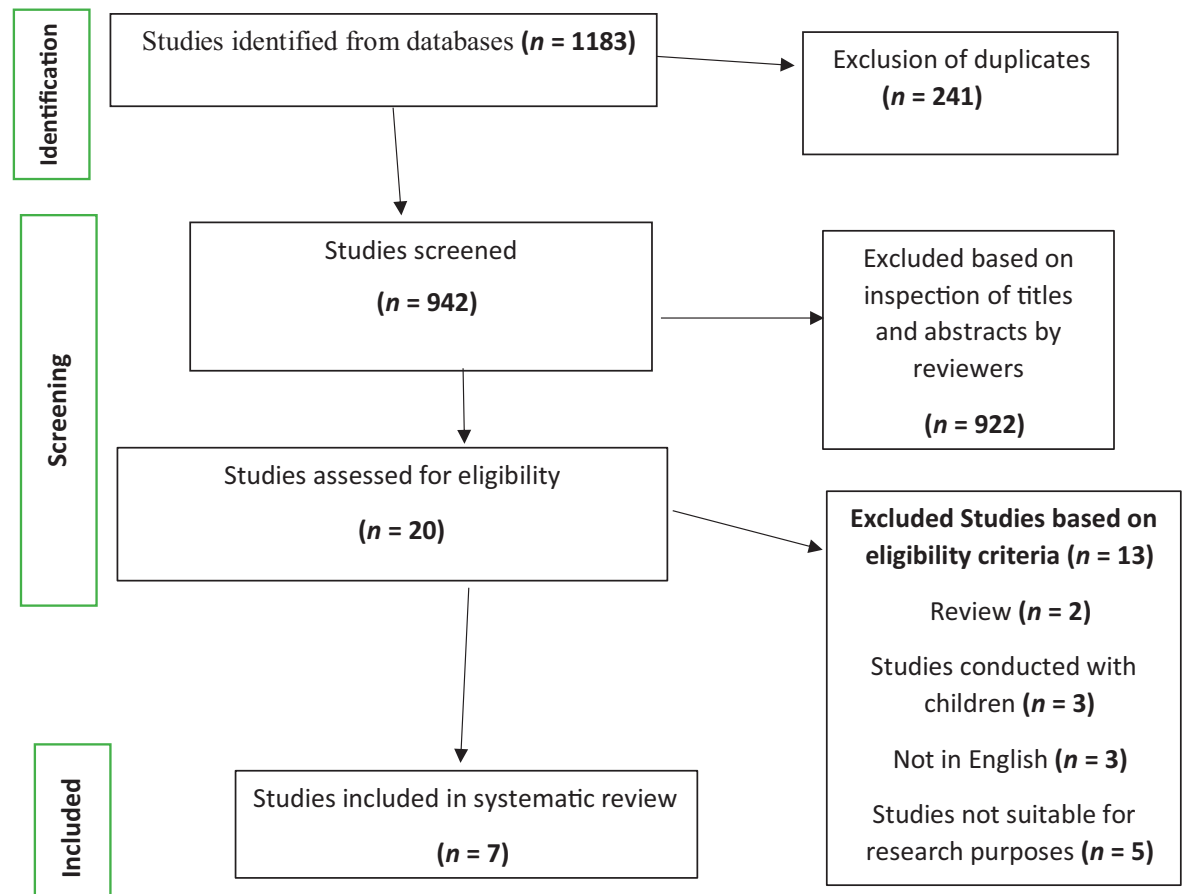

Thenmozhi and Pauline [12] applied lavender oil onto the skin in the AVF region for 5 min before the intervention. The control group received standard routine hospital care. The application was made in three consecutive hemodialysis sessions. The mean pretest and posttest mean pain scores in the experiment and control groups were as 2.31 and 4.34, respectively. The researchers concluded that the topical application of lavender oil was effective.

In their study of the effects of aromatherapy on pain and xerosis after repeated needle placement into the fistula arm in hemodialysis patients, Kilic Akca et al. [30] applied massage to the experiment group with lavender oil for a total of 12 sessions, which occurred three times a week and for 4 weeks. The second group received olive oil massage for the same duration. The third group received only standard care practices. Among the group receiving lavender oil, the pain score was 5.23 before the intervention. It was reduced to 2.43 after the intervention. The mean Visual Analog Scale (VAS) scores for the aromatherapy and olive oil massage groups for acute pain after intervention were found to be significantly lower than that of the control group $(p<0.001)$.

Tasan et al. [31] examined the effects of diluted lavender oil inhalation on pain development during vascular access in patients receiving hemodialysis treatment. Tasan et al. [31] dripped three drops of lavender oil onto a sterile sponge and placed the sponge at $10 \mathrm{~cm}$ from the nose of the patient. The patient inhaled the lavender oil for an average of $3-5 \mathrm{~min}$ in the experimental group. The control group received routine care. This implementation was carried out in three consecutive hemodialysis sessions. The mean pain score of the patients in the experimental group was 3.8 before lavender oil inhalation. The mean pain score decreased to 3.0 after lavender oil inhalation. This change was found to be statistically significant $(\phi<0.05)$. 


\begin{tabular}{|c|c|c|c|c|c|c|c|c|}
\hline No & Year & Author Name(s) & Type of study & Sample & Scale & $\begin{array}{l}\text { Method of } \\
\text { application }\end{array}$ & Results & $\begin{array}{l}\text { Effect of } \\
\text { aromatherapy }\end{array}$ \\
\hline 1 & 2020 & Reyes et al. [9] & $\begin{array}{l}\text { Quasi- } \\
\text { experimental } \\
\text { study }\end{array}$ & $\begin{array}{l}\text { Group } \\
1: 25 \\
\text { Group } \\
2: 25\end{array}$ & $\begin{array}{l}\text { The } \\
\text { numeric } \\
\text { rating } \\
\text { scale } \\
\text { (NRS) }\end{array}$ & Inhalation & \multirow{7}{*}{$\begin{array}{l}\text { Pain was } \\
\text { significantly } \\
\text { lower in the } \\
\text { experimental } \\
\text { group } \\
\text { In the } \\
\text { experimental } \\
\text { group, the pain } \\
\text { was significantly } \\
\text { reduced as a } \\
\text { result of topical } \\
\text { application } \\
\text { The mean VAS } \\
\text { scores for post- } \\
\text { intervention pain } \\
\text { were significantly } \\
\text { lower than the } \\
\text { control group } \\
\text { Pain levels were } \\
\text { significantly } \\
\text { lower in the } \\
\text { experimental } \\
\text { group } \\
\text { Pain levels were } \\
\text { significantly } \\
\text { lower in the } \\
\text { experimental } \\
\text { group } \\
\text { Pain was } \\
\text { significantly } \\
\text { lower in the } \\
\text { experimental } \\
\text { group } \\
\text { The mean VAS } \\
\text { scores for post- } \\
\text { intervention pain } \\
\text { were significantly } \\
\text { lower than the } \\
\text { control group }\end{array}$} & 1193 \\
\hline 2 & 2020 & $\begin{array}{l}\text { Thenmozhi and } \\
\text { Pauline [12] }\end{array}$ & $\begin{array}{l}\text { Randomized } \\
\text { controlled } \\
\text { experimental } \\
\text { study }\end{array}$ & $\begin{array}{l}\text { Group } \\
1: 15 \\
\text { Group } \\
2: 15\end{array}$ & $\begin{array}{l}\text { The } \\
\text { numeric } \\
\text { rating } \\
\text { scale } \\
\text { (NRS) }\end{array}$ & Topical & & \\
\hline 3 & 2020 & $\begin{array}{l}\text { Kilic Akca et al. } \\
\text { [30] }\end{array}$ & $\begin{array}{l}\text { Randomized } \\
\text { controlled } \\
\text { experimental } \\
\text { study }\end{array}$ & $\begin{array}{l}\text { Group } \\
1: 25 \\
\text { Group } \\
2: 25 \\
\text { Group } \\
3: 25\end{array}$ & $\begin{array}{l}\text { Visual } \\
\text { analogue } \\
\text { scale } \\
\text { (VAS) }\end{array}$ & Topical & & \\
\hline 4 & 2019 & Tasan et al. [31] & $\begin{array}{l}\text { Randomized } \\
\text { controlled } \\
\text { experimental } \\
\text { study }\end{array}$ & $\begin{array}{l}\text { Group } \\
1: 30 \\
\text { Group } \\
2: 30\end{array}$ & $\begin{array}{l}\text { Visual } \\
\text { analogue } \\
\text { scale } \\
\text { (VAS) }\end{array}$ & Inhalation & & \\
\hline 5 & 2016 & $\begin{array}{l}\text { Aliasgharpour } \\
\text { et al. [32] }\end{array}$ & $\begin{array}{l}\text { Quasi- } \\
\text { experimental } \\
\text { study }\end{array}$ & $\begin{array}{l}\text { Group } \\
1: 20 \\
\text { Group } \\
2: 20\end{array}$ & $\begin{array}{l}\text { Visual } \\
\text { analogue } \\
\text { scale } \\
\text { (VAS) }\end{array}$ & Inhalation & & \\
\hline 6 & 2015 & Ghods et al. [8] & $\begin{array}{l}\text { Randomized } \\
\text { controlled } \\
\text { experimental } \\
\text { study }\end{array}$ & $\begin{array}{l}\text { Group } \\
1: 17 \\
\text { Group } \\
2: 17\end{array}$ & $\begin{array}{l}\text { The } \\
\text { numeric } \\
\text { rating } \\
\text { scale } \\
\text { (NRS) }\end{array}$ & Topical & & $\begin{array}{r}\text { Table } 3 . \\
\text { Characteristics of the }\end{array}$ \\
\hline 7 & 2014 & $\begin{array}{l}\text { Bagheri- } \\
\text { Nesami et al. } \\
\text { [33] }\end{array}$ & $\begin{array}{l}\text { Randomized } \\
\text { controlled } \\
\text { experimental } \\
\text { study }\end{array}$ & $\begin{array}{l}\text { Group } \\
1: 46 \\
\text { Group } \\
2: 46\end{array}$ & $\begin{array}{l}\text { Visual } \\
\text { analogue } \\
\text { scale } \\
\text { (VAS) }\end{array}$ & Inhalation & & $\begin{array}{r}\text { studies included in the } \\
\text { systematic review of } \\
\text { effect of aromatherapy } \\
\text { on arteriovenous } \\
\text { fistula puncture on } \\
\text { hemodialysis patients, } \\
2010-2020\end{array}$ \\
\hline
\end{tabular}

Aliasgharpour et al. [32] dropped three drops of an aromatherapy mixture including lavender extract onto a piece of cotton. Patients in the experiment group inhaled lavender oil from a distance of 7-10 $\mathrm{cm}$ before placement of the needle. The control group received routine interventions. Pain severity was measured at every stage in three consecutive hemodialysis seasons after lavender aromatherapy application. The pain score of the control group increased from 5.36 to 5.58. However, the pain score of the experimental group decreased from 4.00 to 2.97 , and the decrease was statistically significant.

Ghods et al. [8] sprayed lavender oil three times onto the AVF intervention region in the experiment group and waited for 5 min after each spray. In the placebo group, water was sprayed three times onto the AVF intervention region, and the researchers waited for $5 \mathrm{~min}$ after each spray. The control group did not receive any intervention. The intervention was applied for two consecutive times, and pain was assessed in an interval of $72 \mathrm{~h}$. The pain 
JHR

36,6 intensity was determined as 2.91 after topical lavender essential oil application, 4.18 after placebo application and 1.66 without any intervention. The difference in severity of pain among these three groups was significant $(\phi=0.001)$.

Bagheri-Nesami et al. [33] dripped three drops of lavender oil onto a piece of cotton. The cotton was placed at $10 \mathrm{~cm}$ from the nose of the patient. The patient breathed it for an average of 3-5 $\mathrm{min}$ in the experiment group. The control group received placebo aromatherapy for $5 \mathrm{~min}$. These interventions were repeated in three consecutive hemodialysis sessions. Before the intervention, the mean VAS pain intensity scores in the experimental and control groups were 3.78 and $4.16(p=0.35)$. After three aromatherapy sessions, the mean VAS scores in the experiment and control groups were 2.36 and 3.43, and the difference was statistically significant $(p=0.009)$.

\section{Discussion}

In hemodialysis patients, pain is a disturbing experience that is experienced during insertion of the fistula needle in every dialysis session. It is highly important to achieve pain management for patients receiving hemodialysis treatment. Holistic nursing interventions are frequently used in pain management [34-36]. Lakhan et al. [37] reported that aromatherapy was more effective in reducing pain in comparison to control and placebo groups. In all studies included in our study, it was determined that aromatherapy reduced the pain levels of fistula needle interventions in hemodialysis patients.

By triggering mechanisms in the brain by stimulating the olfactory system with essential oils, aromatherapy blocks the pain nerve messages of the sodium flow in nerve fibers transmitting pain by blocking the sodium channels [38]. It also stimulates the receptors in the olfactory bulb, transmits the message to the limbic system and causes secretion of endorphin, encephalin and serotonin. With the secretion of these hormones, there is relaxation in the individual, which causes pain and stress to decrease [12]. In our review, researchers used the inhalation method $(n=4)$ and topical application method $(n=3)$ (Table 3).

Reyes et al. [9], Tasan et al. [31], Aliasgharpour et al. [32] and Bagheri-Nesami et al. [33] used the inhalation method for aromatherapy application in their studies. While Reyes et al. [9] used sweet orange extract oil in aromatherapy, Tasan et al. [31], Aliasgharpour et al. [32] and Bagheri-Nesami et al. [33] used lavender oil. In the inhalation method, the lavender oil was used by dilution with sweet almond oil at a ratio of 1:10. Lavender oil is frequently preferred to relieve pain and stress, support immunity and eliminate skin problems [39].

While inhalation aromatherapy provides smell stimulation only, topical aromatherapy application achieves both smell stimulation and touch stimulation [40, 41]. The topical application of aromatherapy reduces pain by preventing painful stimuli from reaching the CNS. This is achieved by stimulating receptors with secretion of endogenous substances such as endorphin [42]. In the topical application of aromatherapy, lavender oil is preferred as the safest method [43]. Ghods et al. [8], Thenmozhi and Pauline [12], Kilic Akca et al. [30] applied lavender oil topically onto the skin in the AVF region. It was determined that pain significantly decreased as a result of this application.

Most of the studies in this systematic review used lavender oil for pain relief. The reasons for choosing lavender oil include that it is easily available, popular, has a good smell and has a known mechanism of action [44-46].

\section{Conclusion}

We observed different practices with different aromatherapeutic oils. Nevertheless, researchers reported that pain decreased for each of these different practices. Thus, we conclude that application of aromatherapy during the fistula needle intervention in 
hemodialysis patients reduces pain. Studies have used different oils and different application methods (topical, inhalation, etc.). Therefore, nurses may select the practices that they will apply on patients based on the patient's status. In the future, we recommend that researchers conduct meta-analyses and subgroup analysis to obtain more accurate results on this topic.

As a result of our literature review, we determined that aromatherapy application in hemodialysis patients provided positive effects on reducing pain during fistula needle intervention. As aromatherapy application is an easy and relatively harmless practice, this method may be used as a practical method in pain management in nursing. However, we recommend that more studies are conducted to confirm these claims.

Conflict of Interest: None

\section{References}

1. Jafari-Koulaee A, Moosazadeh M, Bagheri Nesami M, Goudarzian AH. Effect of cryotherapy on arteriovenous fistula puncture-related pain in hemodialysis patients: a systematic review and meta-analysis. Complement Ther Med. 2020; 49: 102326. doi: 10.1016/j.ctim.2020.102326.

2. Bouya S, Balouchi A, Rafiemanesh H, Hesaraki M. Prevalence of chronic kidney disease in Iranian general population: a meta-analysis and systematic review. Ther Apher Dial. 2018; 22(6): 594-9. doi: 10.1111/1744-9987.12716.

3. Isakova T, Nickolas TL, Denburg M, Yarlagadda S, Weiner DE, Gutierrez OM, et al. KDOQI US commentary on the 2017 KDIGO clinical practice guideline update for the diagnosis, evaluation, prevention, and treatment of chronic kidney disease-mineral and bone disorder (CKD-MBD). Am J Kidney Dis. 2017; 70(6): 737-51. doi: 10.1053/j.ajkd.2017.07.019.

4. Khalil E, Akalin C. Effectiveness and safety of using a novel endothelial damage inhibitor in arteriovenous fistula formation. J Surg Med. 2020; 4(9): 716-9. doi: 10.28982/josam.788906.

5. Kallenbach JZ. Review of hemodialysis for nurses and dialysis personnel. St. Louis, Missouri, Mo: Mosby; 2020.

6. Alzaatreh MY, Abdalrahim MS. Management strategies for pain associated with arteriovenous fistula cannulation: an integrative literature review. Hemodial Int. 2020; 24(1): 3-11. doi: 10.1111/hdi.12803.

7. da Silva OM, Rigon E, Corradi Dalazen JV, Bissoloti A, Rabelo-Silva ER. Pain during arteriovenous fistula cannulation in chronic renal patients on hemodialysis. Open J Nurs. 2016; 6(12): 1028-37. doi: 10.4236/ojn.2016.612098.

8. Ghods AA, Abforosh NH, Ghorbani R, Asgari MR. The effect of topical application of lavender essential oil on the intensity of pain caused by the insertion of dialysis needles in hemodialysis patients: a randomized clinical trial. Complement Ther Med. 2015; 23(3): 325-30. doi: 10.1016/j.ctim. 2015.03.001.

9. Reyes M, Reyes M, Ribay KGL, Paragas ED Jr. Effects of sweet orange aromatherapy on pain and anxiety during needle insertion among patients undergoing hemodialysis: a quasi-experimental study. Nurs Forum. 2020; 55(3): 425-32. doi: 10.1111/nuf.12447.

10. Al Hasbi H, Chayati N, Makiyah SNN. Progressive muscle relaxation to reduces chronic pain in hemodialysis patient. MEDISAINS. 2019; 17(3): 62-6. doi: 10.30595/medisains.v17i3.5823.

11. Borzou SR, Anosheh M, Mohammadi E, Kazemnejad A. Patients' perception of comfort facilitators during hemodialysis procedure: a qualitative study. Iran Red Crescent Med J. 2014; 16(7): e19055. doi: $10.5812 /$ ircmj.19055.

12. Thenmozhi P, Pauline KB. Effectiveness of lavender oil application on pain during arteriovenous fistula puncture. Int J Adv Nephrol Res. 2020; 3(1): 37-43.

13. Ali B, Al-Wabel NA, Shams S, Ahamad A, Khan SA, Anwar F. Essential oils used in aromatherapy: a systemic review. Asian Pac J Trop Biomed. 2015; 5(8): 601-11. doi: 10.1016/j.apjtb.2015.05.007.

14. Cook N, Lynch J. Aromatherapy: reviewing evidence for its mechanisms of action and CNS effects. Br J Neurosci Nurs. 2008; 4(12): 595-601. doi: 10.12968/bjnn.2008.4.12.31963. 
JHR

36,6

1196

15. Alok K, Rakesh T, Sushil K. Aromatherapy - an alternative health care through essential oils. J Med Aromatic Plant Sci. 2000; 22(1B): 798-804.

16. Svoboda KP, Deans SG. A study of the variability of Rosemary and Sage and their volatile oils on the British market: their antioxidative properties. Flavour Fragr J. 1992; 7(2): 81-7. doi: 10.1002/ffj. 2730070207.

17. Jimbo D, Kimura Y, Taniguchi M, Inoue M, Urakami K. Effect of aromatherapy on patients with Alzheimer's disease. Psychogeriatrics. 2009; 9(4): 173-9. doi: 10.1111/j.1479-8301.2009.00299.x.

18. Koulivand PH, Khaleghi Ghadiri M, Gorji A. Lavender and the nervous system. Evid Based Complement Alternat Med. 2013; 2013: 681304. doi: 10.1155/2013/681304.

19. Price S, Price L. Aromatherapy for health professionals. Edinburgh: Churchill Livingstone; 2011.

20. Varney E, Buckle J. Effect of inhaled essential oils on mental exhaustion and moderate burnout: a small pilot study. J Altern Complement Med. 2013; 19(1): 69-71. doi: 10.1089/acm.2012.0089.

21. Tisserand R, Young R. Essential oil safety: a guide for health care professionals. Edinburgh: Churchill Livingstone/Elsevier; 2013.

22. Ozer Z, Ates S. Pain and pain management in hemodialysis patients. Istanbul Sabahattin Zaim UniversityJournal ofInstitute Sci Technology. 2020; 2(2): 1-7.

23. Murthy V, Sibbritt DW, Adams J. An integrative review of complementary and alternative medicine use for back pain: a focus on prevalence, reasons for use, influential factors, selfperceived effectiveness, and communication. Spine J. 2015; 15(8): 1870-83. doi: 10.1016/j.spinee. 2015.04.049.

24. Henley DV, Lipson N, Korach KS, Bloch CA. Prepubertal gynecomastia linked to lavender and tea tree oils. N Engl J Med. 2007; 356(5): 479-85. doi: 10.1056/NEJMoa064725.

25. Oyedeji AO, Afolayan AJ, Hutchings A. Compositional variation of the essential oils of Artemisia afra Jacq. from three provinces in South Africa-a case study of its safety. Nat Prod Commun. 2009; 4(6): 849-52.

26. Page MJ, McKenzie JE, Bossuyt PM, Boutron I, Hoffmann TC, Mulrow CD, et al. Updating guidance for reporting systematic reviews: development of the PRISMA 2020 statement. J Clin Epidemiol. 2021; 134: 103-12. doi: 10.1016/j.jclinepi.2021.02.003.

27. Salameh JP, Bossuyt PM, McGrath TA, Thombs BD, Hyde CJ, Macaskill P, et al. Preferred reporting items for systematic review and meta-analysis of diagnostic test accuracy studies (PRISMA-DTA): explanation, elaboration, and checklist. BMJ. 2020; 370: m2632. doi: 10.1136/bmj.m2632.

28. Higgins JP, Altman DG, Gotzsche PC, Juni P, Moher D, Oxman AD, et al. The Cochrane Collaboration's tool for assessing risk of bias in randomised trials. BMJ. 2011; 343: d5928. doi: 10. 1136/bmj.d5928.

29. Joanna Briggs Institute [JBI]. Critical appraisal tools. [updated 2017; cited 2020]. Available at: https://joannabriggs.org/critical-appraisal-tools.

30. Kilic Akca N, Akbuga GA, Arslan DE, Senturk S. Aromatherapy massage for pain and xerosis after repeated needle insertion into a fistula arm in hemodialysis. Altern Ther Health Med. 2021; 27(3): 39-45.

31. Tasan E, Ovayolu O, Ovayolu N. The effect of diluted lavender oil inhalation on pain development during vascular access among patients undergoing haemodialysis. Complement Ther Clin Pract. 2019; 35: 177-82. doi: 10.1016/j.ctcp.2019.02.010.

32. Aliasgharpour M, Abbaszadeh R, Mohammadi N, Kazemnejad A. Effect of lavender aromatherapy on the pain of arteriovenous fistula puncture in patients on hemodialysis. Nurs Pract Today. 2016; 3(1): $26-30$.

33. Bagheri-Nesami M, Espahbodi F, Nikkhah A, Shorofi SA, Charati JY. The effects of lavender aromatherapy on pain following needle insertion into a fistula in hemodialysis patients. Complement Ther Clin Pract. 2014; 20(1): 1-4. doi: 10.1016/j.ctcp.2013.11.005. 
34. Andrews-Cooper IN, Kozachik SL. How patient education influences utilization of nonpharmacological modalities for persistent pain management: an integrative review. Pain Manag Nurs. 2020; 21(2): 157-64. doi: 10.1016/j.pmn.2019.06.016.

35. Surya M, Zuriati Z, Zahlimar, Poddar S. Nursing aromatherapy using lavender with rose essence oil for post-surgery pain management. Enferm Clin. 2020; 30(Suppl 5): 171-4. doi: 10.1016/j.enfcli. 2020.02.001.

36. Varaei S, Jalalian Z, Yekani Nejad MS, Shamsizadeh M. Comparison the effects of inhalation and massage aromatherapy with lavender and sweet orange on fatigue in hemodialysis patients: a randomized clinical trial. J Complement Integr Med. 2020; 18(1): 193-200. doi: 10.1515/jcim2018-0137.

37. Lakhan SE, Sheafer H, Tepper D. The effectiveness of aromatherapy in reducing pain: a systematic review and meta-analysis. Pain Res Treat. 2016; 2016: 8158693. doi: 10.1155/2016/ 8158693.

38. Dobetsberger C, Buchbauer G. Actions of essential oils on the central nervous system: an updated review. Flavour Fragr J. 2011; 26(5): 300-16. doi: 10.1002/ffj.2045.

39. Bulut E, Cilingir D. The use of aromatherapy in the control of perioperative symptoms. J Education Res Nurs. 2020; 17(S1): 115-21.

40. Guo P, Li P, Zhang X, Liu N, Wang J, Yang S, et al. The effectiveness of aromatherapy on preoperative anxiety in adults: a systematic review and meta-analysis of randomized controlled trials. Int J Nurs Stud. 2020; 111: 103747. doi: 10.1016/j.jnurstu.2020.103747.

41. Chen H, Sun L, Du Z, Zhao L, Wang L. A cross-sectional study of mental health status and selfpsychological adjustment in nurses who supported Wuhan for fighting against the COVID-19. J Clin Nurs. 2020; 29(21-22): 4161-70. doi: 10.1111/jocn.15444.

42. Tolasa AG, Akyol A. Use of aromaterapy in dialysis patients. J Nephrol Nurs. 2017; 12(2): 84-90.

43. Antonelli M, Donelli D. Efficacy, safety and tolerability of aroma massage with lavender essential oil: an overview. Int J Ther Massage Bodywork. 2020; 13(1): 32-6.

44. Kavurmaci M, Kucukoglu S, Tan M. Effectiveness of aromatherapy in reducing test anxiety among nursing students. Indian J Traditional Knowledge. 2015; 1(1): 52-6.

45. Kim S, Kim HJ, Yeo JS, Hong SJ, Lee JM, Jeon Y. The effect of lavender oil on stress, bispectral index values, and needle insertion pain in volunteers. J Altern Complement Med. 2011; 17(9): 823-6. doi: 10.1089/acm.2010.0644.

46. Karaman T, Karaman S, Dogru S, Tapar H, Sahin A, Suren M, et al. Evaluating the efficacy of lavender aromatherapy on peripheral venous cannulation pain and anxiety: a prospective, randomized study. Complement Ther Clin Pract. 2016; 23: 64-8. doi: 10.1016/j.ctcp.2016.03.008.

\section{Corresponding author}

Ayşegül Yıldız can be contacted at: aysegul.yildiz@kapadokya.edu.tr

For instructions on how to order reprints of this article, please visit our website:

www.emeraldgrouppublishing.com/licensing/reprints.htm

Or contact us for further details: permissions@emeraldinsight.com 